\title{
A teljesexom-szekvenálás jelentősége a ritka neurológiai betegségek diagnosztikájában - saját tapasztalatok egy ataxiás eset kapcsán
}

\author{
Balicza Péter dr. ${ }^{1}$. Grosz Zoltán dr. ${ }^{1}$ - Bencsik Renáta ${ }^{1}$. Illés Anett ${ }^{1}$ \\ Gál Anikó dr. ${ }^{1}$. Gézsi András dr. ${ }^{2}$ - Molnár Mária Judit dr. ${ }^{1}$ \\ ${ }^{1}$ Semmelweis Egyetem, Általános Orvostudományi Kar, \\ Genomikai Medicina és Ritka Betegségek Intézete, Budapest \\ ${ }^{2}$ Budapesti Műszaki és Gazdaságtudományi Egyetem, Villamosmérnöki és Informatikai Kar, \\ Méréstechnika és Információs Rendszerek Tanszék, Budapest
}

\begin{abstract}
Az új generációs szekvenálási eljárások alkalmazásának elterjedése lényegesen átalakítja a ritka neurogenetikai betegségek diagnosztikáját. Egyes neurológiai tünetek, úgymint az ataxia hátterében számos szerzett és öröklött tényező is állhat, sőt egy adott gén különböző variációi is számos fenotípussal jelentkezhetnek. Emiatt a hagyományos egygénszekvenálási vizsgálatok gyakran nem tudják tisztázni a betegség hátterét. Az új generációs szekvenálás lehetőséget nyújt egyszerre akár 50-100 gén szekvenálására is, ezek az úgynevezett panelvizsgálatok, illetve ha a klinikum nem segít a betegség stratifikálásában, a teljesexom-szekvenálási vizsgálatok nyújthatnak lehetőséget az atípusos klinikummal jelentkező genetikai betegségek azonosítására. Esetismertetésünk egy cerebellaris ataxiás beteg teljesexom-szekvenálási eredményét mutatja be. A vizsgálatok egy hereditaer spasticus paraparesissel asszociációban leírt génben, az SPG11-ben találtak olyan ritka variánsokat, amelyek összefüggésbe hozhatók a klinikai tünetekkel. Közleményünkkel arra szeretnénk felhívni a figyelmet, hogy egyes esetekben a vezető prezentációs tünet variabilitása nagymértékben nehezíti a megfelelő génpanel kiválasztását. A jelen esetben a hereditaer spasticus paraparesishez asszociált gén eltérései primeren cerebellaris ataxiát okoztak, melyet egy kizárólagos ataxia új generációs szekvenálási panelvizsgálat sem derített volna fel.
\end{abstract}

Orv Hetil. 2018; 159(28): 1163-1169.

Kulcsszavak: neurogenetika, új generációs szekvenálás, SPG11, ataxia

\section{Significance of whole exome sequencing in the diagnostics of rare neurological diseases - own experiences through a case presenting with ataxia}

\begin{abstract}
Next generation sequencing (NGS) technologies reshape the diagnostics of rare neurological diseases. In the background of certain neurological symptoms, such as ataxia, many acquired and genetic causes may be present. Variations in a given gene can present with variable phenotypes, too. Because of this phenomenon, the conventional one gene sequencing approach often fails to identify the genetic background of a disease. Next generation sequencing panels allow to sequence 50-100 genes simultaneously, and if the disease stratification is not possible based on the clinical symptoms, whole exome sequencing can help in the diagnostic of genetic disorders with atypical presentation. This case study is about the exome sequencing of a patient with cerebellar ataxia. Genetic investigations identified rare variants in the SPG11 gene in association with the clinical phenotype, which gene was originally described in the background of hereditary spastic paraparesis. Our article highlights that in certain cases the variability of the leading presenting symptom makes it hard to select the correct gene panel. In our case the variants in the gene, formerly associated to hereditary spastic paraparesis, resulted in cerebellar ataxia initially, so even an ataxia NGS gene panel would not detect those.
\end{abstract}

Keywords: neurogenetics, next generation sequencing, SPG11, ataxia

Balicza P, Grosz Z, Bencsik R, Illés A, Gál A, Gézsi A, Molnár MJ. [Significance of whole exome sequencing in the diagnostics of rare neurological diseases - own experiences through a case presenting with ataxia]. Orv Hetil. 2018; 159(28): 1163-1169.

(Beérkezett: 2018. január 9.; elfogadva: 2018. február 10.) 


\section{Rövidítések}

$\mathrm{ALD}=$ adrenoleukodystrophia; ALS = amyotrophiás lateralsclerosis; $\mathrm{AMN}=$ adrenomyeloneuropathia; $\mathrm{AOA}=$ ataxia, oculomotoros apraxia; COX = citokrómoxidáz; FXTAS = fragilis X-hez kötött tremor-ataxia szindróma; GATK = Genome Analysis Toolkit; $\mathrm{HH}=$ hypogonadotrop hypogonadismus; HLD = hypomyelinisatióval társuló leukodystrophia; $\mathrm{HPO}=$ (human phenotype ontology) humánfenotípus-ontológia; HSAN = hereditaer sensoros és autonóm neuropathia; HSN = hereditaer sensoros neuropathia; HSP = hereditaer spasticus paraparesis; INDEL = insertio/deletio; JALS = juvenilis amyotrophiás lateralsclerosis; $\mathrm{MAF}=$ minor allélfrekvencia; $\mathrm{MR}=$ mágneses rezonancia; $\mathrm{MTDPS}=$ mitochondrialis DNSdepletiós szindróma; NBIA = (neurodegeneration with brain iron accumulation) agyi vastárolással járó neurodegeneráció; NGS = (next generation sequencing) új generációs szekvenálás; $\mathrm{PEO}=($ progressive external ophthalmoplegia $)$ progresszív külső szemizombénulás; SANDO = sensoros ataxia, neuropathia, dysarthria, ophthalmoparesis; SCA = spinocerebellaris ataxia; $\mathrm{SPAX}=$ spasticus ataxia; $\mathrm{VCF}=($ variant call format $)$ variánshívási formátum

A neurológiai diagnosztikában egy-egy tünet hátterében számos alkalommal nagyon heterogén etiológia állhat. Érvényes ez még abban az esetben is, ha egyértelmúen el tudjuk különíteni az örökletes és a szerzett betegségeket. $\mathrm{Az}$ ataxiák differenciáldiagnosztikája kapcsán számos szerzett betegséget kell kizárnunk ahhoz, hogy azt mondhassuk: biztosan örökletes formáról van szó. A beteg anamnesztikus adatai, pontos családfaelemzés és az alapos klinikai vizsgálat nagyon sokat segíthet a leggyakoribb örökletes ataxiaformák felismerésében, ennek ellenére az esetek többségében feltáratlan marad a pontos genetikai háttér. Abban az esetben, ha a leggyakoribb célzott egygén-vizsgálatok nem hoznak eredményt, úgynevezett új generációs génpaneleket (20-100 gén egyidejü vizsgálata) választhatunk a genetikai diagnosztika alapjául, de számos esetben ezek a panelvizsgálatok sem hoznak eredményt. Ilyen esetekben, ha alapos a gyanú, hogy genetikusan meghatározott formáról van szó, a teljesexom-vizsgálatok kivételesen lehetőséget nyújthatnak a rejtély megoldására.

Az új generációs szekvenálási eljárások (next generation sequencing, NGS) [1] alkalmazásának elterjedése jelentősen megváltoztatta a ritka neurogenetikai betegségek diagnosztikáját. A technológia Magyarországon is egyre inkább hozzáférhetôvé válik (bár még nem közfinanszírozottan), és tekintve a neurogenetikai megbetegedések széles palettáját, alkalmazását egyre inkább igényelnék a klinikusok. Bár az egyes mendeli betegségek előfordulása külön-külön ritka, összesítve mégis jelentős morbiditási tényezőt képviselnek. A genetikai rendellenességek összesített incidenciája mintegy 40-82/1000 élveszületés [2], amelyek jelentős része (mintegy 60\%-a) elsődlegesen a központi idegrendszert érinti [3]. Így a neurológiaszakma kitüntetett helyet foglal el a genetikai betegségekben szenvedők gondozásában.
A különböző új generációs szekvenálási eljárások lényege a hagyományos Sanger-szekvenáláshoz képest sokszoros áteresztőképesség, a fajlagos szekvenálási idő jelentős mértékű rövidülése mellett [4]. A rövid DNSszakaszok parallel vizsgálatával és a költségek csökkenésével elérhetővé vált a teljes kódoló génállomány (exom) klinikai vizsgálata. Az exomszekvenálás költsége a kereskedelemben meglehetősen széles ártartományban mozog. A https://genohub.com/ adatbázisa alapján 20-szoros lefedettség mellett 534-7515 USD között változik, amely több tényezőtől függ, azonban megbízható, rövid átfutási idejű (<15 nap), orvosi értelmezést is magában foglaló vizsgálat már 1500 EUR-ért Európában is elérhető. Összevetésként egyetlen gén Sangerszekvenálásának költsége, a gén méretétől függően, elérheti a 800 EUR-t [5].

\section{Célkitüzés}

Egy eset bemutatásán keresztül szeretnénk felhívni közleményünkkel a figyelmet a technológiára, illusztrálva annak előnyeit és nehézségeit.

\section{Esetismertetés}

A 18 éves férfi beteg 11 éves korában induló vizsgálatakor már zavaró mértékű, progresszív kézremegés miatt jelentkezett járóbeteg-rendelésünkön. A kézremegésen kívül további panaszként feledékenységet, valamint nyelési nehezítettséget, beszédének megváltozását is említette. A heteroanamnézis szerint 15-16 éves kora óta észlelték a lábak „befelé fordulását”, amely a járásában zavarja. Távolabbi anamnézisében eseménytelen perinatalis időszak, megfelelő ütemben zajló motoros fejlődés szerepelt. Az iskolát 8 évesen kezdte, iskolaérettségi vizsgálata kapcsán fáradékonyságot, beilleszkedési zavart, beszédzavara miatt logopédiai kezelést, hiányos általános tájékozottságot, jobb-bal tévesztést, a figyelmi múködés zavarát, térbeli orientációs nehézségeket állapítottak meg. A kézremegés jelentkezését megelőző iskolai években már észlelték fokozatosan romló írásképét, majd dyslexiát, dysgraphiát, dyscalculiát állapítottak meg.

Neurológiai fizikális vizsgálata során finom tekintésirányú horizontalis nystagmust, enyhe fokú cerebellaris dysarthriát, kétoldali felső végtagi posturalis, intencióra kifejezetten fokozódó tremort, mindkét felső végtagban dysdiadochokinesist, a bokaízületekben enyhe (Ashworth-skála szerinti 2.) fokú spasticitast észleltünk. A betegnek paresise nem volt. A saját reflexek testszerte közepesen élénkek voltak, pyramisjeleket nem észleltünk. A neuropszichológiai vizsgálat a beteg korához képest kifejezett memóriadeficitet, elsősorban előhívási zavart, valamint az absztrakciós képesség enyhe sérülését igazolta.

Több alkalommal történt koponya-MR-vizsgálat (15, 18, 19 éves korában). Ezeken az oldalkamrák pereme mentén - kitüntetetten a frontalis kamraszarvak előtt - 
FLAIR hiperintenzív jelzavar ábrázolódott, amely az évek alatt jelentős progressziót nem mutatott (1. ábra).

$\mathrm{Az}$ általános laboratóriumi paraméterek és a hasi ultrahangvizsgálat nem mutatott eltérést. A szérumban a coeruloplazmin és a réz szintje a referenciatartományon belül volt. A beteg szemészeti vizsgálata nem igazolt eltérést, Kayser-Fleischer-gyúrü nem volt jelen. A szérum oxiszterolvizsgálata C-típusú Niemann-Pick-betegség irányában nem igazolt eltérést. A differenciáldiagnosztika során felvetődő mitochondrialis betegség miatt elvégzett izomszövettani vizsgálat részeként a fénymikroszkópos vizsgálat minor aspecifikus elváltozásokat mutatott. Az oxidatív enzimreakciók megoszlása több festéssel is egyenetlen volt, néhány izomrostban a COXfestés halványabb volt a szokottnál (2. ábra), több izomrostban apró vakuólák ábrázolódtak. Az elektronmikroszkópia néhány izomrostban a mitochondriumokat megnagyobbodottnak, helyenként degradáltnak találta, bennük helyenként osmophil anyag felhalmozódását lehetett észlelni (2. ábra). Bár maternalis öröklődés nem volt jelen, a miopatológiai elváltozások felvetették a mitochondrialis betegség gyanúját. A terheléses szérum-laktátszintek vizsgálata azonban nem igazolt oxidatív anyagcsere-károsodást, és a mitochondrialis DNS-ben a hot spotok helyén (mtDNS-deletio, A3243G, C8344T, G893T) mutációk nem igazolódtak. Mivel az ataxia volt a legkifejezettebb prezentációs tünet, az SCA1,2,3,6,7, APTX, SETX, TTPE, FRDA gének elemzését is elvégeztük, és azokban eltérést nem találtunk. Az APTX, SETX, TTPE, FRDA gének vizsgálata a PTE Orvosgenetikai Intézetében készült. A fiatal

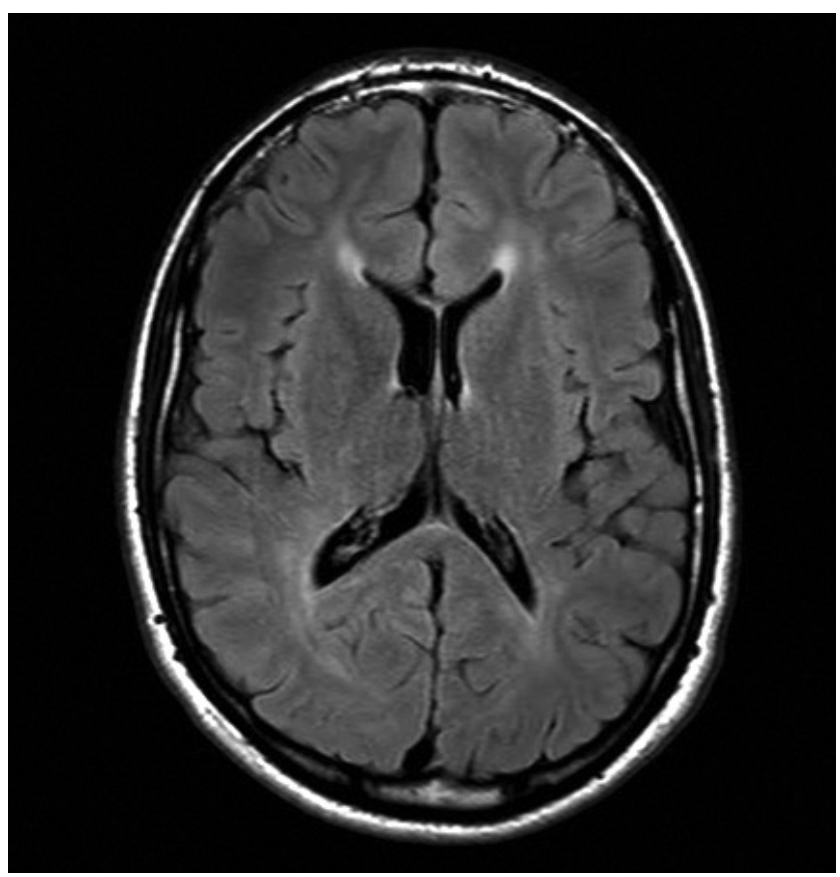

\begin{tabular}{l|l} 
1. ábra $\quad$ Indexbetegünk axialis síkú MR-képe
\end{tabular}

Az axialis síkú FLAIR-szekvenciákon a frontalis és occipitalis kamraszarvak körül ábrázolódik sapkaszerü hiperintenzitás korban jelentkező tremorra és a kognitív funkciózavarra való tekintettel az FMRl-gén vizsgálatát is elvégeztük, bár a klinikai kép nem volt a fragilis X-hez kötött tremor-ataxia szindrómára (FXTAS) jellegzetes. Ezt a gént is normálisnak találtuk. Mivel az extenzív vizsgálatok sem tudták tisztázni a betegség molekuláris hátterét, a beteg fiatal életkorára való tekintettel teljesexom-szekvenálást végeztünk.

\section{A teljesexom-szekvenálás módszertana}

Az exomszekvenálás során triómódszert alkalmaztunk, azaz az érintett indexpáciens mellett a tünetmentes szülőknél is elvégeztük a szekvenálást. Erre azért van szükség, mert ha nem ismert patogén variánst azonosítunk az elemzés során, a valószínúleg patogén és a bizonytalan jelentőségű variánsok minősítését nagymértékben segíti a szülők variánsainak ismerete. A teljesexom-szekvenálást Nextera Rapid Capture kit segítségével, Illumina HiSeq2500 platformon végeztük el. A variánshívás a GATK-ajánlások szerint történt [6]. A variánsfájlok (VCF) annotálására az SnpEff szoftvert használtuk [7]. A variánsok szűrésére kombinált megközelítést alkalmaztunk. A variánsok fenotípus szerinti automatizált szűrésére az Exomiser nevú programot [8] alkalmaztuk, amelyben HPO-keresőkulcsokként az ataxia [HP: 0001251], intenciós tremor [HP: 0002080], alsó végtagi spasticitas [HP: 0002061] kifejezéseket adtuk meg. A variánsok manuális szürésưre a Gézsi András által fejlesztett „VariantAnalyser” szoftvert alkalmaztuk, és a következő stratégiát követtük. 1) Nagy és közepes hatású variációk (stopvariációk, frameshiftet okozó insertiók, deletiók, splice variációk, missense variációk) megtartása. 2) $5 \%$ feletti minor allélfrekvenciával bíró variációk kizárása. 3) A proteinfunkciót megváltoztató variánsok megtartása. A nonsense mutációkat és kereteltolódást okozó insertiókat, deletiókat, amennyiben a klinikumnak megfelelő génben, a feltételezett öröklésmenetnek megfelelően voltak megtalálhatók, patogénnek tekintettük. A nem szinonim, aminosavcserét eredményező variációkat a proteinpredikciós szoftverek (SIFT, Polyphen2, GERP) által adott pontszámok alapján priorizáltuk. 4) A compound heterozigóta öröklésmenetnek megfelelő, illetve a homozigóta géneltéréseket előnyben részesítettük, tekintve a negatív családi anamnézist. 5 ) Az OMIMadatbázisban szereplő gének előnyben részesítése. 6) További manuális szürés fenotípus alapján. Az új generációs szekvenálással azonosított patogén mutációkat Sanger-szekvenálással megerősítettük. A variánsok végső értékelése során az American College of Medical Genetics ajánlását [9] követtük. A vizsgálatokhoz ETT-TUKEBengedéllyel rendelkeztünk (4459-2/2013/EKU $[535 / 2013])$. A beteg a genetikai vizsgálatokat megelőzően genetikai tanácsadáson vett részt, és a vizsgálatba írásos tájékozott beleegyezést adott. 

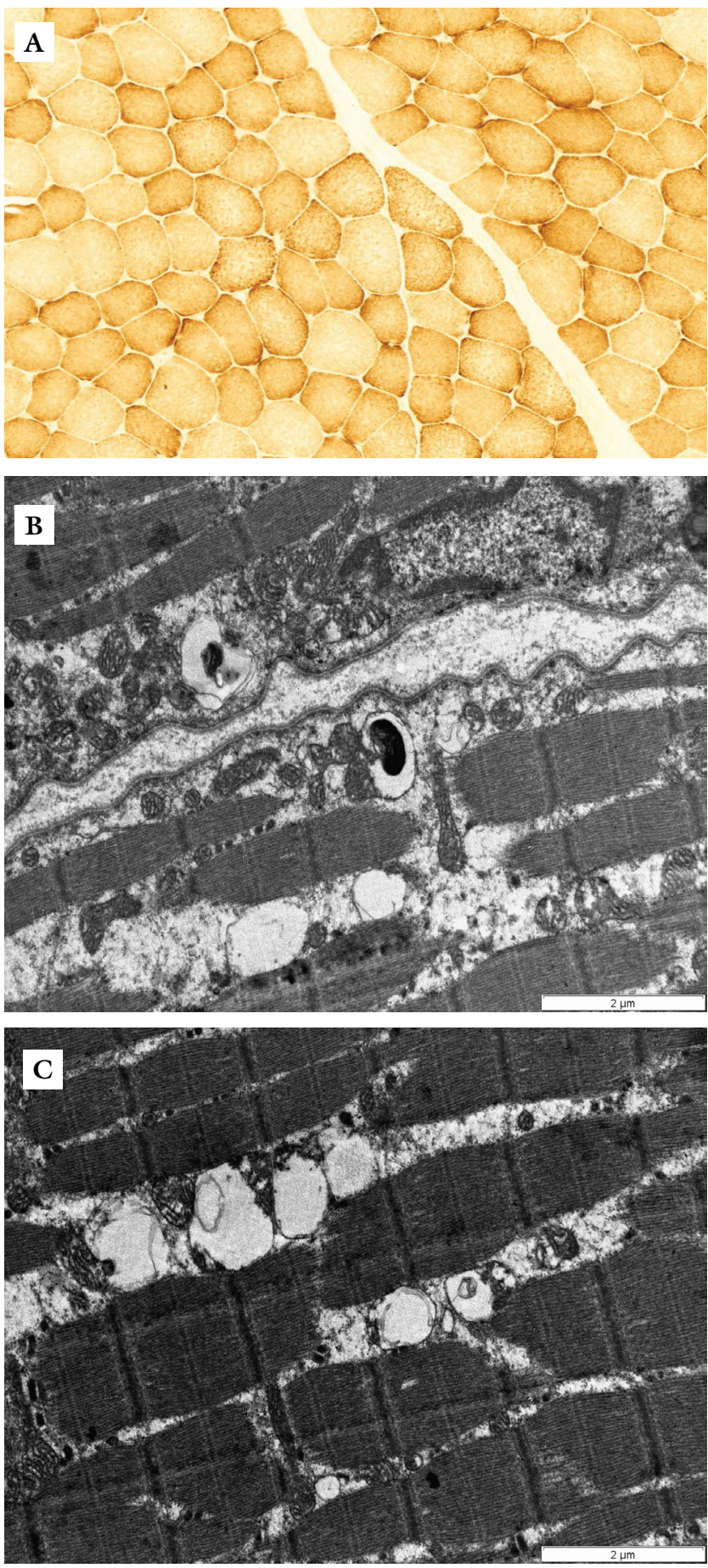

2. ábra $\quad$ Izomszövettani képek

A) A COX-festéssel készült keresztmetszeti fénymikroszkópos izommetszeteken (10× nagyítás) egyes izomrostok festődése halványabb. B-C) Az elektronmikroszkópos felvételeken (20 000× nagyítás) helyenként megnagyobbodott, illetve subsarcolemmalisan degenerált szerkezetû́ mitochondriumok láthatók (C), valamint intermyofibrillarisan a kis mitochondriumok szomszédságában lipid vakuólák figyelhetôk meg

\section{Eredmények}

Tizenötszörös lefedettség mellett az exomi régiók 88,2 (index), 88,8 (apa), 92,9\%-a (anya), 20-szoros lefedettség mellett $64,3,73,6,83,0$ százaléka került szekvenálásra.

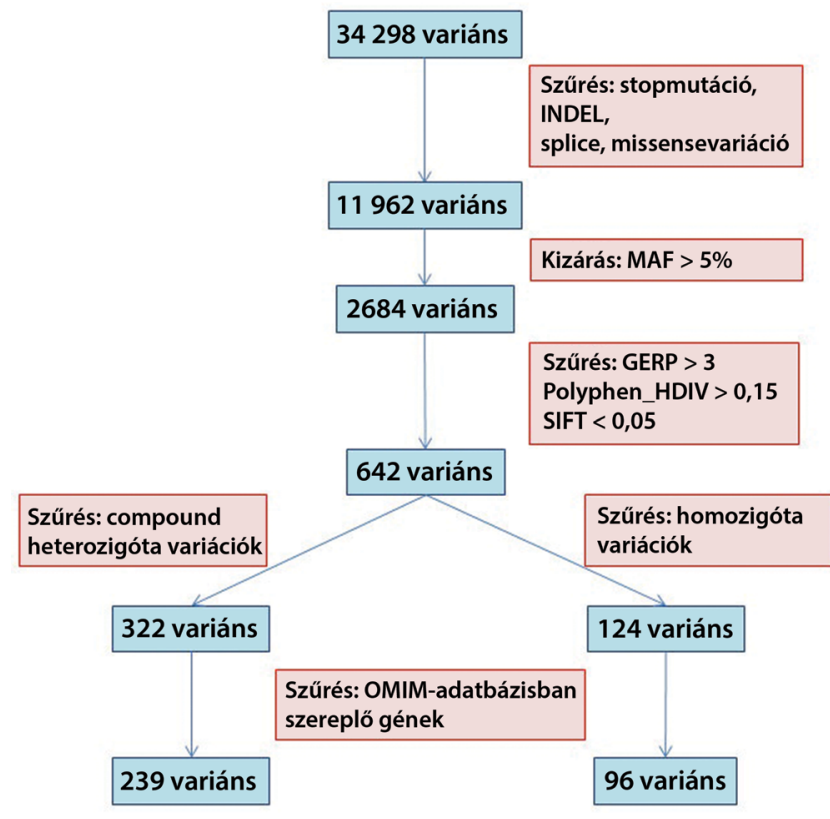

3. ábra $\quad$ A variánsok manuális szürésének lépései

$\mathrm{Az}$ átlagos lefedettség 28,6× (index), 38,5× (apa), 51,7× (anya) volt. Az indexpáciens mintájában alapvető minőségi szűréseket követően 28763 exoni variáció került azonosításra. Az Exomiser programban ataxia [HP: 0001251], intenciós tremor [HP: 0002080], alsó végtagi spasticitas [HP: 0002061] kifejezéseket megadva, 1\% alatti minor allélfrekvenciás határt szabva, PhenIX algoritmus használatával 5838 variáns maradt fent, amelyeket a program rangsorolt. A top 10 géntalálat az 1 . táblázatban látható, míg a manuális szûrés lépéseit a 3. ábra mutatja.

A manuális szưréssel 335 ritka, deletáns variáció maradt fenn. A további lépésekben a compound heterozigóta öröklésmenetnek nem ellentmondó variációkat tovább szürtük. Előnyben részesítettük azokat a variánsokat, amelyeknél azonosítható volt, hogy az egyik heterozigóta variáns az egyik szülőtől, míg az egyazon génben elhelyezkedő másik heterozigóta variáns a másik szülőtől származik. A fennmaradó compound heterozigóta és homozigóta variánsokat fenotípus szerint áttekintve azonosítottunk az SPG11-génben két kereteltolódással járó INDEL-t (2. táblázat). A találatok közül az elsődleges kandidáns az SPG11-gén volt, amely az Exomiser által felállított kandidáns génlistán az ötödik helyen szerepelt. A két variáció egy-egy leolvasási kereteltolódással járó INDEL, amelynek egyik tagja (p. 1026fs*4) ismerten patogén [10], a másik tagja korábban az irodalomban nem reportált eltérés. A Sangerszekvenálással történt szegregációs vizsgálat konfirmálta a variációk jelenlétét, valamint hogy a két allél transzpozícióban helyezkedik el. A kiszürt SPG11-gén ismeretében, a koponya-MR-felvételeket ismételten megtekintve azonosítottuk az elvékonyodott corpus callosumot (4. ábra), amely a feltételezett etiológiát tovább erősítette. 
1. táblázat $\mid$ Az Exomiser szoftver top 10 gén találata

\begin{tabular}{|c|c|c|c|}
\hline Gén & Exomiser-pont & Asszociált betegségek & Öröklődés \\
\hline \multirow{2}{*}{ GJC2 } & \multirow{2}{*}{0,996} & Hypomyelinisatióval járó leukodystrophia 2 (HLD2) & AR \\
\hline & & Spasticus paraparesis 44 (SPG44) & $\mathrm{AR}$ \\
\hline \multirow{2}{*}{ ITPRI } & \multirow[t]{2}{*}{0,957} & Spinocerebellaris ataxia 29 (SCA29) & $\mathrm{AD}$ \\
\hline & & Spinocerebellaris ataxia 15 (SCA15) & $\mathrm{AD}$ \\
\hline \multirow{2}{*}{$A B C D 1$} & \multirow{2}{*}{0,887} & Adrenoleukodystrophia (ALD) & XLR \\
\hline & & Adrenomyeloneuropathia (AMN) & XLR \\
\hline \multirow{4}{*}{ KIFIA } & \multirow{4}{*}{0,887} & Spasticus paraparesis 30 (SPG30) & AR \\
\hline & & Hereditaer sensoros neuropathia IIC (HSN2C) & $\mathrm{AR}$ \\
\hline & & Autoszomális domináns mentális retardáció 9 (MRD9) & $\mathrm{AD}$ \\
\hline & & Hereditaer sensoros és autonóm neuropathia 2 (HSAN2) & $\mathrm{AR}$ \\
\hline \multirow{2}{*}{ SPG11 } & \multirow{2}{*}{0,865} & Spasticus paraparesis 11 (SPGl l) & $\mathrm{AR}$ \\
\hline & & Juvenilis amyotrophiás lateralsclerosis (JALS) & $\mathrm{AR}$ \\
\hline \multirow{2}{*}{ AFG3L2 } & \multirow{2}{*}{0,814} & Spinocerebellaris ataxia 28 (SCA28) & $\mathrm{AD}$ \\
\hline & & Spasticus ataxia 5 (SPAX5) & AR \\
\hline WDR 45 & 0,789 & Agyi vastárolással járó neurodegeneráció 5 (NBIA5) & XLD \\
\hline \multirow{5}{*}{$P O L G$} & \multirow{5}{*}{0,631} & Progresszív külső szemizombénulás (PEO) & $\mathrm{AD}$ \\
\hline & & Progresszív külső szemizombénulás (PEO) & $\mathrm{AR}$ \\
\hline & & Mitochondrialis DNS-depletiós szindróma 4A (MTDPS4A) & $\mathrm{AR}$ \\
\hline & & Mitochondrialis DNS-depletiós szindróma 4B (MTDPS4B) & $\mathrm{AR}$ \\
\hline & & Sensoros ataxia, neuropathia, dysarthria, ophthalmoparesis (SANDO) & $\mathrm{AR}$ \\
\hline \multirow{2}{*}{ SETX } & \multirow{2}{*}{0,676} & Amyotrophiás lateralsclerosis 4 (ALS4) & $\mathrm{AD}$ \\
\hline & & Ataxia, oculomotoros apraxia $2(\mathrm{AOA} 2)$ & $\mathrm{AR}$ \\
\hline \multirow{3}{*}{ CHD7 } & \multirow{3}{*}{0,584} & CHARGE-szindróma & $\mathrm{AD}$ \\
\hline & & Hypogonadotrop hypogonadismus 5 (HH5) & $\mathrm{AD}$ \\
\hline & & Kallmann-szindróma & $\mathrm{AD}$ \\
\hline
\end{tabular}

CHARGE $=$ (coloboma, heart defects, atresia choanae, retarded growth and development, genital abnormalities, ear abnormalities) coloboma, szívdefektusok, choanalis atresia, növekedési retardáció, genitális rendellenességek, fülrendellenességek

2. táblázat | Manuális szűréssel azonosított patogén compound heterozigóta variációk az SPG11-génben

\begin{tabular}{llllll}
\hline Gén & Transzkript & Variáció (HGVS) & Aminosavváltozás & MAF & rs-szám \\
\hline SPG11 & NM_025137.3 & c.5128_5129delCA & p.Q1710fs*9 & - & - \\
\hline SPG11 & NM_025137.3 & c.3075dupA & p.E1026fs*4 & - & rs312262752 \\
\hline
\end{tabular}

\section{Következtetések}

Az SPG1l-gén variációi széles fenotípusspektrummal jelentkezhetnek. Egyaránt okozhatnak autoszomális recesszív öröklésmenettel komplikált hereditaer spasticus paraparesist, perifériás neuropathiát, valamint juvenilis amyotrophiás lateralsclerosist. Az SPG11-asszociált komplikált HSP gyakran fiatal felnőtt korban kezdődik, gyakran kíséri kognitív hanyatlás és ritkábban cerebellaris ataxia [11]. Az ataxia nem konzisztensen jelentkezik, és általában ha jelen van, akkor enyhe, és nem a betegség vezető tünete. Egy korábbi esetközlést ismerünk az iro- dalomból, amelyben akciós tremor volt a prezentációs tünet [12]. Egyes esetekben parkinsonizmus [13], illetve centrális retinadegeneráció [10] kísérheti a spasticus paraparesist. Az SPG11-gén okozta hereditaer spasticus paraparesisre jellemző radiológiai eltérés, az elvékonyodott corpus callosum mellett a már preklinikai stádiumban észlelheto „hiúzfüljel”, amely a frontalis kamraszarvak csúcsán jelentkező, jellegzetes alakú, kóros szignálintenzitás [14]. Az SPG11-asszociált Charcot-Marie-Toothbetegség lassú progressziót mutató, döntően distalis, sensomotoros axonalis neuropathia képében jelentkezik, fiatal felnőttkori kezdettel, amelyet egyes esetekben 


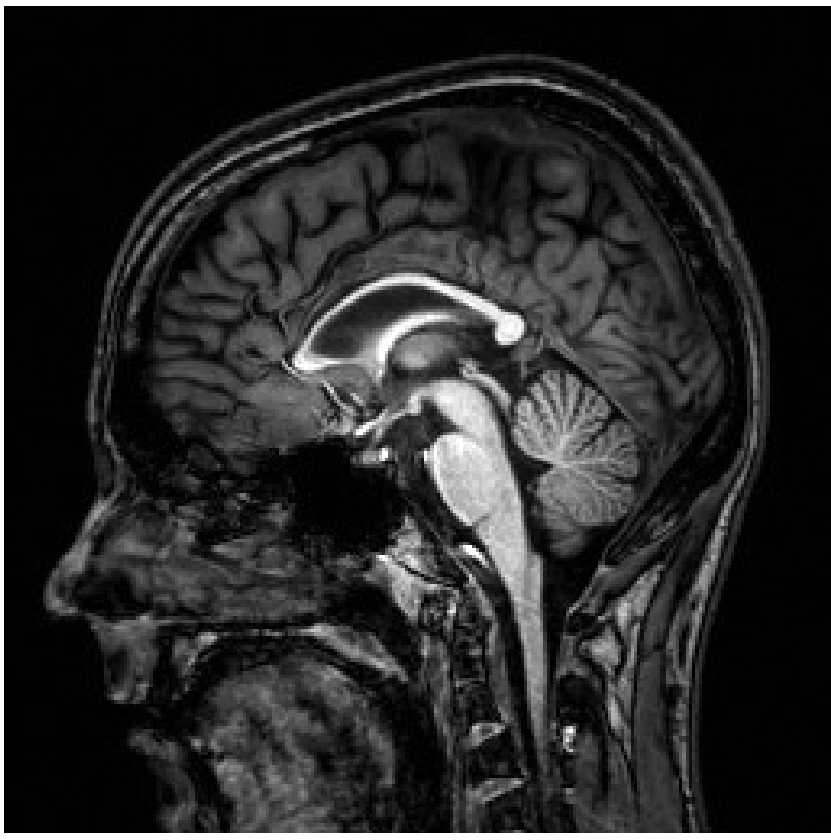

4. ábra

Az indexbeteg sagittalis síkú MR-felvétele

A sagittalis síkú, Tl-súlyozott felvételen megtartott cerebellaris volumen mellett kismértékben elvékonyodott corpus callosum ábrázolódik

mentális retardáció, vékony corpus callosum kísér [15]. $\mathrm{Az}$ amyotrophiás lateralsclerosissal jelentkező betegek esetében korai kezdet (átlag 16. év) és hosszú lefolyás (átlag 34 év) jellemző [16]. Esetünk további bizonyítékul szolgál arra, hogy elsődlegesen ataxiával jelentkező betegnél az SPG1 l lehetőségét figyelembe kell venni, és célzottan kell keresni az MR-en a corpus callosum vékonyodását, még akkor is, ha arról a radiológiai lelet nem nyilatkozik.

Az SPG11 által kódolt spatacsin diszfunkciója nem teljes mértékben tisztázott módon vezet axonalis károsodáshoz. A fehérje károsodása kóros cytoskeletonstabilitással és axonalis transzporttal jár [17]. Emellett a lizoszomális rendszer sem múködik megfelelően, lizoszomálislipid-akkumuláció alakul ki [18]. A HSP patomechanizmusában egyes gének mutációja esetén (SPG13, REEP1, SPG7, C12ORF65, MT-ATP6) mitochondrialis diszfunkció áll a betegség hátterében [19], ezt azonban az SPG11-mutációkkal kapcsolatban eddig nem írták le [13, 20, 21]. Szisztematikus izomszövettani vizsgálatról azonban nincs tudomásunk az SPG11-gén-mutációval asszociált esetekben. További vizsgálatokat igényel, hogy az esetünknél észlelt mitochondrialis eltérések összefüggenek-e az SPG11-deficientiával.

$\mathrm{Az}$ örökletes ataxiák molekuláris diagnosztikája gyakran nagy kihívást jelent, és éveket vehet igénybe. A cerebellaris ataxiák háttere nagyon heterogén, az autoszomális domináns, autoszomális recesszív, X-hez kötött öröklődésû mintegy 58 típus mellett a mitochondrialis gének variációi is állhatnak a háttérben [22]. A spasticus ataxiák esetében további nehézséget okozhat annak el- döntése, hogy hereditaer ataxia formájával állunk-e szemben, amelyben spasticitas kíséri a tüneteket, vagy a hereditaer spasticus paraparesisek valamelyik komplikált esetéról van szó [23]. Bár klinikai paraméterek segíthetnek szúkíteni a szóba jövő gének listáját, pusztán klinikai alapon az egyes ataxiatípusok elkülönítése gyakran nem lehetséges, és több gén vizsgálatára van szükség. Esetünkben az exomszekvenálást megelőzően 10 gén vizsgálata történt meg, és mintegy két év telt el az első jelentkezéstől. Exomszekvenálás segítségével valamennyi, ataxiához és HSP-hez kötött gént (egyéb gének mellett) parallel van módunk vizsgálni. A lelet kiadásához szükséges időt ekkor már az adatelemzési nehézségek szabják meg elsősorban.

Az exomszekvenálás előnye, egyben nehézsége a hipotézismentes vizsgálat lehetősége. Az elmúlt évek exomvizsgálatai számos esetben hoztak váratlan genetikai találatokat, bebizonyosodott, hogy különböző gének mutációi vezethetnek ugyanolyan fenotípushoz, és markánsan különböző fenotípusok hátterében állhat ugyanannak a génnek a mutációja [24], amelyre az SPG11gén-variációk különböző fenotípusos megjelenési formái is példát adnak. Nehézséget jelent, hogy az exomszekvenálás értékelése során 20 000 variációból szükséges kiszưrnünk a mendeli betegségért felelős $1-2$ variációt [25]. Ebben az eset kapcsán bemutatott módszerek adhatnak segítséget. Az elmúlt években a genetikai variánsok proteinre kifejtett hatásának in silico vizsgálata mellett egyre nagyobb szerepet kap a fenotípusos jellegek, az úgynevezett fenom, informatikai módszerekkel segített elemzése is [26]. Bár a bioinformatikai módszerek révén a kandidáns génlistát a legtöbb esetben pár százas listára le tudjuk szúkíteni, a végleges diagnózishoz még ekkor is gondos mérlegelésre, biológus, klinikai genetikus, informatikus együttmúködésére van szükség.

Jelenleg a ritka betegségeknek csak kis részében érhető el specifikus terápia (a neurológia területéről pozitív példaként említhetők a Duchenne-izomdystrophia egyes típusai, a Fabry-, a Pompe-kór, a spinalis muscularis atrophia, a sclerosis tuberosa). Fontosnak tartjuk azonban kiemelni, hogy a molekuláris diagnózis azokban az esetekben is befolyásolja a beteg sorsát, amikor specifikus terápia nem áll rendelkezésre: a molekuláris diagnózis mentesíti a beteget a további hosszadalmas és szükségtelen vizsgálatoktól. Elkerülhetővé válnak szükségtelen kezelések. A betegséghez társuló, az első vizsgálatkor még nem jelen lévő szövődmények monitorozhatóvá válnak. Klinikai vizsgálati lehetőségek nyílhatnak meg a beteg számára. A diagnózis biztossá válása pszichológiai előnyökkel jár a beteg és családja számára. Pontos adatok nyújthatók a betegnek a prognózissal, öröklésmenettel kapcsolatban. Fiatal betegek esetében a molekuláris diagnózisnak a családtervezés szempontjából is kiemelt szerepe van. Összességében tehát elmondható, hogy minden genetikai betegség esetében molekuláris diagnózisra szükséges törekednünk, amelynek a teljesexomszekvenálás kiváló eszköze lehet. 
Anyagi támogatás: A közlemény megírását a Nemzeti Agykutatási Program KTIA_NAP_13_1-2013-0001. számú pályázata támogatta.

Szerzôi munkamegosztás: B. P.: Betegvizsgálat, az exomszekvenálási adatok értékelése, irodalomkutatás, a közlemény megírása. G. Z.: Betegvizsgálat, a kézirat kritikus átolvasása. B. R., I. A., Gál A.: A genetikai vizsgálatok laboratóriumi elvégzése. Gézsi A.: Az exomszekvenálási adatok értékelése. M. M. J.: Betegvizsgálat, a közlemény megírása, irodalomkutatás, a kézirat kritikus átolvasása. A cikk végleges változatát valamennyi szerző elolvasta és jóváhagyta.

Érdekeltségek: A szerzőknek nincsenek érdekeltségeik.

\section{Köszönetnyilvánítás}

Köszönettel tartozunk az esetközlésben szereplő betegnek a vizsgálatban történő részvételért és a PTE Orvosgenetikai Intézet igazgatójának, Prof. Melegh Bélának és munkatársainak az APTX, SETX, TTPE, FRD $A$ gének vizsgálatáért.

\section{Irodalom}

[1] Mihály Z, Győrffy B. Next generation sequencing technologies (NGST) development and applications. [Következő generációs szekvenálási technológiák kifejlődése és alkalmazásai.) Orv Hetil. 2011; 152: 55-62. [Hungarian]

[2] Yang Y, Muzny DM, Reid JG, et al. Clinical whole-exome sequencing for the diagnosis of Mendelian disorders. N Engl J Med. 2013; 369: 1502-1511.

[3] Federico A. Rare neurological diseases: A Pandora's box for neurology (an European and Italian perspective). Rev Neurol. 2013; 169: S12-S17.

[4] Goodwin S, McPherson JD, McCombie WR. Coming of age ten years of next-generation sequencing technologies. Nat Rev Genet. 2016; 17: 333-351.

[5] Fogel BL, Satya-Murti S, Cohen BH. Clinical exome sequencing in neurologic disease. Neurol Clin Pract. 2016; 6: 164-176.

[6] DePristo MA, Banks E, Poplin R, et al. A framework for variation discovery and genotyping using next-generation DNA sequencing data. Nat Genet. 2011; 43: 491-498.

[7] Cingolani P, Platts A, Wang LL, et al. A program for annotating and predicting the effects of single nucleotide polymorphisms, SnpEff: SNPs in the genome of Drosophila melanogaster strain $\mathrm{w}^{1118}$; iso-2; iso-3. Fly (Austin) 2012; 6: 80-92.

[8] Robinson PN, Köhler S, Oellrich A, et al. Improved exome prioritization of disease genes through cross-species phenotype comparison. Genome Res. 2014; 24: 340-348.

[9] Richards S, Aziz N, Bale S, et al. Standards and guidelines for the interpretation of sequence variants: a joint consensus recommendation of the American College of Medical Genetics and Genomics and the Association for Molecular Pathology. Genet Med. $2015 ; 17: 405-423$
[10] Örlén H, Melberg A, Raininko R, et al. SPG11 mutations cause Kjellin syndrome, a hereditary spastic paraplegia with thin corpus callosum and central retinal degeneration. Am J Med Genet Part B 2009; 150B: 984-992.

[11] Schüle R, Schlipf N, Synofzik M, et al. Frequency and phenotype of SPG1 1 and SPG15 in complicated hereditary spastic paraplegia. J Neurol Neurosurg Psychiatry 2009; 80: 1402-1404.

[12] Schneider SA, Mummery CJ, Mehrabian M, et al. SPGll presenting with tremor. Tremor Other Hyperkinet Mov. 2012; 2: tre-02-104-666-1.

[13] Anheim M, Lagier-Tourenne C, Stevanin G, et al. SPGl I spastic paraplegia: A new cause of juvenile parkinsonism. J Neurol. 2009; 256: 104-108.

[14] Riverol M, Samaranch L, Pascual B, et al. Forceps minor region signal abnormality "ears of the lynx": An early MRI finding in spastic paraparesis with thin corpus callosum and mutations in the spatacsin gene (SPG11) on chromosome 15. J Neuroimaging 2009; 19: 52-60.

[15] Montecchiani C, Pedace L, Lo Giudice T, et al. ALS5/SPG1 l/ KIAA1840 mutations cause autosomal recessive axonal Charcot-Marie-Tooth disease. Brain 2016; 139: 73-85.

[16] Su XW, Broach JR, Connor JR, et al. Genetic heterogeneity of amyotrophic lateral sclerosis: Implications for clinical practice and research. Muscle Nerve 2014; 49: 786-803.

[17] Pérez-Brangulí F, Mishra HK, Prots I, et al. Dysfunction of spatacsin leads to axonal pathology in SPG11-linked hereditary spastic paraplegia. Hum Mol Genet. 2014; 23: 4859-4874.

[18] Branchu J, Boutry M, Sourd L, et al. Loss of spatacsin function alters lysosomal lipid clearance leading to upper and lower motor neuron degeneration. Neurobiol Dis. 2017; 102: 21-37.

[19] Lo Giudice T, Lombardi F, Santorelli FM, et al. Hereditary spastic paraplegia: Clinical-genetic characteristics and evolving molecular mechanisms. Exp Neurol. 2014; 261: 518-539.

[20] Samaranch L, Riverol M, Masdeu JC, et al. SPGII compound mutations in spastic paraparesis with thin corpus callosum. Neurology 2008; 71: 332-336.

[21] Paisan-Ruiz C, Dogu O, Yilmaz A, et al. SPG11 mutations are common in familial cases of complicated hereditary spastic paraplegia. Neurology 2009; 70: 1384-1389.

[22] Mancuso M, Orsucci D, Siciliano G, et al. The genetics of ataxia: Through the labyrinth of the Minotaur, looking for Ariadne's thread. J Neurol. 2014; 261: 528-541.

[23] De Bot ST, Willemsen MA, Vermeer S, et al. Reviewing the genetic causes of spastic-ataxias. Neurology 2012; 79: 1507-1514.

[24] Zoghbi HY, Warren ST. Neurogenetics: Advancing the "nextgeneration" of brain research. Neuron 2010; 68: 165-173.

[25] Bamshad MJ, Ng SB, Bigham AW, et al. Exome sequencing as a tool for Mendelian disease gene discovery. Nat Rev Genet. 2011; 12: 745-755.

[26] Smedley D, Robinson PN. Phenotype-driven strategies for exome prioritization of human Mendelian disease genes. Genome Med. 2015; 7: 81 .

(Balicza Péter dr., Budapest, Tömő u. 25-29., 1083 e-mail: balicza.peter@med.semmelweis-univ.hu) feltéve, hogy az eredeti szerző és a közlés helye, illetve a CC License linkje és az esetlegesen végrehajtott módosítások feltüntetésre kerülnek. 